\title{
CYCLE 7 E DAN PENGETAHUAN AWAL TERHADAP KETERAMPILAN BERPIKIR KRITIS SISWA PADA PEMBELAJARAN IPA DI KELAS V SD
}

\author{
${ }^{1}$ Riri Marfilinda, ${ }^{2}$ Yanti Fitria, ${ }^{2}$ Sufyarma Marsidin \\ 1ririmarfilinda@gmail.com, ${ }^{2}$ yantifitria@gmail.com \\ ${ }^{1}$ STKIP Adzkia Padang, \\ ${ }^{2,3}$ Universitas Negeri Padang
}

\begin{abstract}
ABSTRAK
Tujuan dari penelitian ini untuk melihat pengaruh model Learning Cycle 7 E terhadap keterampilan berpikir kritis siswa dan pengaruh pengetahuan awal tinggi dan rendah terhadap keterampilan berpikir kritis. Penelitian ini merupakan penelitian jenis quasi eksperimen dengan rancangan penelitian menggunakan faktorial $2 \times 2$. Populasi dalam penelitian ini adalah seluruh siswa kelas V SDIT Adzkia Padang dengan teknik pengambilan sampel pada penelitian ini adalah simple random sampling. Data penelitian diperoleh dari tes pengetahuan awal dan tes keterampilan berpikir kritis. Data dianalisis dengan Anava. Hasil penelitian menunjukan bahwa pada rata-rata tes akhir (posttest) berdasarkan perhitungan anava satu arah diperoleh Fhitung $=6,21$ pada taraf $\alpha=0,05$ diperoleh Ftabel $=4,023$ karena Fhitung $>$ Ftabel berarti keterampilan berpikir kritis yang menggunakan model Learning Cycle 7E lebih tinggi dibandingkan pembelajaran yang menggunakan metode eksperimen; pada analisis yang kedua didapatkan Fhitung $=9,98$ pada taraf nyata $\alpha=0,05$ dan Ftabel $=4,23$ yang berarti keterampilan Berpikir Kritis dengan pengetahuan awal tinggi menggunakan model Learning Cycle $7 E$ lebih tinggi dibandingkan metode eksperimen; pada analisis ketiga didapatkan Fhitung $=0,65$ pada taraf nyata $\alpha=0,05$ diperoleh Ftabel $=4,30$ yang berarti keterampilan berpikir kritis dengan pengetahuan awal rendah menggunakan model Learning Cycle $7 E$ tidak berbeda dengan pembelajaran menggunakan metode Eksperimen; Dan analisis terakhir menggunakan Uji ANAVA dua arah dengan metode Unweighted mean dimana nilai Fhitung $=4,098$ $>$ Ftabel $=4,00$ yang berarti terdapat interaksi antara model Learning Cycle $7 E$ dan pengetahuan awal dalam mempengaruhi keterampilan berpikir kritis siswa.
\end{abstract}

Kata kunci: Learning Cycle 7 E, Keterampilan Berpikir Kritis, Pengetahuan Awal, IPA SD

\section{PENDAHULUAN}

Perkembangan Ilmu Pengetahuan dan Teknologi (IPTEK) dalam era globalisasi sudah mengalami kemajuan yang pesat. Apalagi dengan akan dihadapkannya pada abad 21 dimana ilmu pengetahuan dan perkembangan kehidupan mengalami pergeseran ciri khas dibandingkan abad sebelumnya yaitu merupakan abad informasi, komputasi, otomasi dan komunikasi. Hal inilah yang menuntut seluruh masyarakat untuk memantapkan diri dalam meningkatkan kualitasnya agar mampu berdaya saing dalam menghadapi tantangan kehidupan yang semakin berat.

$$
\text { Sesuai dengan apa yang }
$$
disampaikan Wagner (dalam Marzano, 2012:4) bahwa pada abad 21, keterampilan dasar seperti membaca, menulis dan matematika tidaklah cukup 
namun dalam menghadapi pekerjaan harus mempunyai keterampilan memecahkan masalah baik secara intelektual maupun teknis. Jadi, disini masyarakat membutuhkan keterampilan yang dibutuhkan pada abad 21, salah satunya keterampilan berpikir kritis dalam menjalani kehidupan sekarang dan masa depan.

Pembelajaran IPA menuntut siswa dengan berbagai aktivitas yang membuat mereka berinteraksi dengan lingkungan, objek nyata, dan hal konkrit lainnya yang berkaitan dengan materi pembelajaran IPA, sehingga nantinya melalui pengalaman yang diperoleh mereka akan lebih mudah untuk meningkatkan rasa ingin tahunya, mampu mengumpulkan informasi sebanyak-banyaknya, menggabungkan informasi, menemukan pola, dan melakukan generalisasi berdasarkan temuannya secara mandiri. Pembelajaran IPA yang seperti ini akan membuat belajar siswa lebih bermakna. Sebagaimana fokus pembelajaran yang bermakna sesuai dengan pandangan bahwa belajar adalah mengkonstruksi pengetahuan, yang di dalamnya siswa berusaha memahami pengalamanpengalaman mereka ( Anderson, dkk, 2010:98) .

Namun sayangnya, berdasarkan pengamatan di lapangan, banyak ditemui pelaksanaan pembelajaran masih kurang variatif dan belum menghasilkan pembelajaran IPA yang bermakna bagi anak. Berdasarkan observasi di SD Adzkia, pembelajaran IPA yang berlangsung belum mampu memenuhi standar pembelajaran IPA seutuhnya. kelas pembelajaran IPA belum banyak menggunakan diskusi, investigasi, dan pekerjaan laboratorium untuk meningkatkan kepahaman dalam belajar IPA. Siswa cenderung menggunakan hafalan sebagai strategi pembelajarannya dan konsep IPA yang diberikan oleh guru belum banyak digunakan oleh siswa dalam memecahkan masalah yang mereka jumpai.

Kemampuan berpikir merupakan salah satu kecakapan hidup yang perlu dipelajari dan dikembangkan melalui proses pendidikan. Johnson (2011:185) mengungkapkan bahwa "Kemampuan berpikir kritis adalah sebuah proses terorganisasi yang memungkinkan siswa mengevaluasi bukti, asumsi, logika, dan bahasa yang mendasari pernyataan orang lain”. Kemampuan berpikir kritis membuat siswa tidak dengan mudah menerima informasi atau pengetahuan dari satu sumber, akan tetapi siswa akan berusaha mencari penjelasan dan alternatif sebanyak-banyaknya untuk menganalisis, mensintesis, dan 
mengevaluasi pengetahuan tersebut

menghasilkan

pengetahuan

hingga pada akhirnya dapat membuat

(Susanto,2013:121).

Keterampilan

generalisasi. Tujuan pengembangan

berpikir dikelompokkan menjadi

kemampuan berpikir kritis baik pada

pembelajaran IPA maupun bidang lainnya

adalah untuk meningkatkan kemampuan

berpikir siswa dalam menghadapi

kehidupan yang dinamis dan selalu

berubah. Hal senada juga diungkapkan

oleh Bailin (2002: 361-375) bahwa saat

ini sudah meluasnya dukungan dan

sambutan terhadap berpikir kritis sebagai

sebuah dimensi yang penting dalam

pembelajaran IPA. Namun pada

kenyataannya, kemampuan berpikir kritis

siswa masih sangat rendah.

Untuk itu perlu adanya pembaharuan dan perbaikan dalam proses pembelajaran yang mengutamakan pencapaian hasil belajar berupa proses dan produk. Salah satu upaya untuk mencapai hasil belajar berupa proses dan produk adalah proses pembelajaran yang berorientasi paradigma konstruktivistik. Salah satunya dengan menggunakan model Learning Cycle $7 E$ dalam pembelajaran.

Berpikir tidak terlepas dari aktivitas manusia ,karena berpikir merupakan ciri yang membedakan antara manusia dengan makhluk lainnya. Berpikir pada umumnya didefinisikan

Berpikir kritis menurut Ennis (dalam Fisher, 2009:4) adalah pemikiran yang masuk akal dan reflektif yang berfokus untuk memutuskan apa yang mesti dipercaya atau dilakukan. Berpikir kritis merupakan kemampuan menggunakan logika. Logika merupakan cara berpikir untuk mendapatkan pengetahuan yang disertai pengkajian kebenarannya berdasarkan pola penalaran tertentu. Selanjutnya, Ennis menyebutkan ada enam unsur dasar dalam berpikir kritis yang disingkat FRISCO, yaitu Focus (fokus), Reason (alasan), Inference (menyimpulkan), Situation (situasi), Clarity (kejelasan) dan Overview (pandangan menyeluruh). (Susanto, 2013:121). 
Klasifikasi berpikir kritis menurut

Ennis dibagi kedalam dua bagian yaitu aspek umum dan aspek yang berkaitan dengan materi pelajaran. Untuk bidang pendidikan maka yang kita perlukan pada aspek yang berkaitan dengan materi pelajaran, yang meliputi : konsep, generalisasi, dan algoritme, serta pemecahan masalah. Berikut ini merupakan indikator-indikator dari masing-masing aspek berpikir kritis yang berkaitan dengan materi pelajaran, yaitu :

'Pertama memberikan penjelasan sederhana, yang meliputi; memfokuskan pertanyaan; (b) mengalisis pertanyaan; dan (c) bertanya dan menjawab tentang suatu penjelasan atau tantangan. Kedua membangun keterampilan dasar, yang meliputi; (a) mempertimbangkan apakah sumber dapat dipercaya;(b) mengamati dan mempertimbangkan suatu laporan hasil observasi. Ketiga, menyimpulkan, yang meliputi;(a) Mendeduksi dan mempertimbangkan hasil deduksi; (b) menginduksi dan mempertimbangkan hasil induksi; dan (c) membuat dan menentukan nilai pertimbangan.Keempat, memberikan penjelasan lanjut, yang meliputi;(a) mendefinisikan istilah dan pertimbangan definisi dalam tiga dimensi;(b) mengidentifikasi asumsi.dan kelima, mengatur strategi dan taktik, yang meliputi;(a) menentukan tindakan;(b) berinteraksi dengan orang lain'.(Susanto, 2013:126)

Oleh karena itu, dalam penelitian ini peneliti mengambil sembilan indikator dalam berpikir kritis yang akan diteliti di Sekolah Dasar IT Adzkia.

Pelaksanakan proses pembelajaran secara maksimal tidak terlepas keterkaitannya dengan pengetahuan awal. Pengetahuan awal merupakan pengetahuan yang dimiliki siswa tentang materi dasar sebagai prasyarat dalam mempelajari materi yang baru. Klausmer (1985) mengemukakan pengetahuan awal seseorang disebut juga dengan skemata atau struktur kognitif yang tersimpan dalam memori jangka panjang sebagai data. Pengetahuan awal merupakan kumpulan dari pengetahuan dan pengalaman individu yang diperoleh sepanjang pengalaman hidup mereka, dan apa yang ia bawa kepada suatu pengalaman belajar baru. Selanjutnya dikatakan juga oleh ahli psikolog seorang anak dianggap mengerti sesuatu bila ia dapat menerapkan pengetahuan yang didapat sebelumnya untuk diterapkan ke pengalaman atau situasi baru (Hapsari, 2016:262).

Oleh karena itu hendaknya sekolah dan guru dapat menyelenggarakan pembelajaran yang 
mendukung perkembangan kognitif siswanya. Salah satuya yaitu dengan menggunakan model Learning Cycle $7 E$ sebagai model yang mengedepankan prinsip kontrutivistik sehingga menghasilkan pembelajaran bermakna.

\section{METODE PENELITIAN}

Jenis penelitian yang digunakan adalah penelitian kuantitatif dalam bentuk Quasi Eksprimental. Design yang menggunakan desain faktorial design (2x2). Sesuai dengan desain penelitian maka penelitian menggunakan dua kelas yaitu kelas eksperimen dan kelas kontrol. Kelas eksperimen adalah kelas yang sengaja diberi perlakuan model Learning Cycle 7 E, sedangkan kelas kontrol menggunakan metode eksperimen berupa praktikum. Variabel dalam penelitian ini terdiri dari (1) variabel bebas yaitu model Learning Cycle $7 E$ (2) variabel terikat yaitu Berpikir kritis siswa dan pengetahuan awal siswa.

Populasi penelitian ini adalah seluruh siswa kelas V SDIT ADZKIA Kecamatan Kuranji dengan jumlah 143 orang. Berdasarkan hasil yang telah didapatkan yaitu data populasi berdistribusi normal, ragam variansi yang homogen, dan memiliki kesamaan rata-rata, maka pengambilan sampel dilakukan dengan cara simple random sampling. Dari populasi didapakan sampel yaitu dua kelas yaitu kelas V raudhah I sebagai kelas eksperimen dan kelas V Thoif 1 sebagai kelas kontrol.

Untuk mencapai tujuan penelitian yang telah ditetapkan perlu disusun prosedur yang sistematis. Secara umum prosedur penelitian dapat dibagi menjadi tiga tahap, yaitu tahap persiapan, pelaksanaan, dan penyelesaian

\section{Tahap Persiapan}

Pada tahap ini, penulis melakukan penetapan jadwal penelitian, persiapan RPP, instrumen penelitian berupa tes (kisikisi, soal uji coba, dan kunci jawaban soal uji coba tes), Mempersiapkan kelas sampel penelitian yaitu kelas eksperimen dan kelas kontrol dan memvalidasi instrumen penelitian.

\section{Tahap Pelaksanaan}

Pada tahap ini, penulis melakukan pembelajaran di kelas eksperimen dengan menggunakan model Learning Cycle $7 E$. Di kelas kontrol diajar oleh guru kelas dengan metode eksperimen berupa praktikum. Pelaksanaan penelitian pada kelas eksperimen dan kelas kontrol dilaksanakan pada materi sifat bahan dan penyusunnya sebanyak $3 \mathrm{x}$ pertemuan.

\section{Tahap Penyelesaian Penelitian}

Tahap ini merupakan akhir penelitian yaitu dengan memberikan tes pengetahuan awal, tes keterampilan berpikir kritis sebelum dan sesudah 
perlakuan pada kelas eksperimen dan kelas kontrol dengan soal yang sama, mengolah dan menganalisis data yang diperoleh dari kelas eksperimen dan kelas kontrol, menarik kesimpulan dan hasil yang diperoleh sesuai dengan analisis yang digunakan dan menyusun laporan penelitian.

\section{HASIL DAN PEMBAHASAN}

\section{Hasil Penelitian}

Data pengetahuan awal pada penelitian ini diperoleh melalui penilaian tes awal yang dilakukan sebelum proses pembelajaran berlangsung di awal pertemuan pertama atau sebelum perlakuan. Tes pengetahuan awal ini dengan memberikan tes tertulis sebanyak 20 soal berbentuk soal pilihan ganda yang diberikan kepada kelas eksperimen dan kontrol. Tes objektif ini dibuat berdasarkan kisi-kisi soal tentang materi perubahan sifat benda. Secara keseluruhan data pengetahuan awal siswa sebelum diberi perlakuan berupa model pembelajaran Learning Cycle $7 E$ mengungkapkan informasi tentang skor tertinggi, skor terendah dan rata-rata dapat dilihat pada gambar 1 berikut ini :

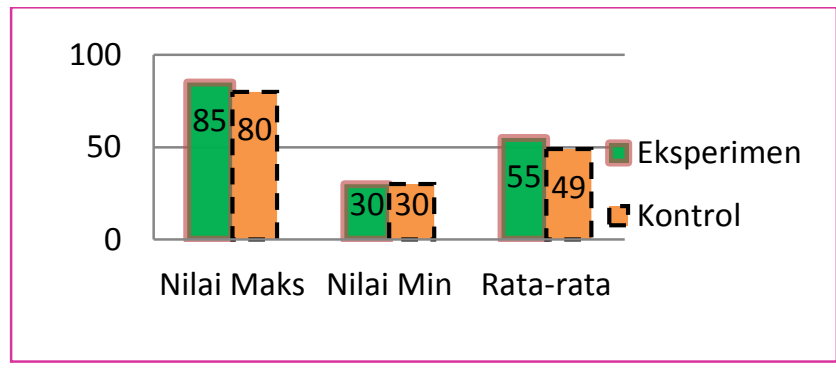

\section{Gambar 1. Sebaran Nilai Pengetahuan Awal Siswa Kelas Eksperimen dan Kontrol}

Data keterampilan berpikir kritis siswa secara keseluruhan di kelas eksperimen dan kelas kontrol yang diperoleh dideskripsikan menurut skor total, skor tertinggi, skor terendah dan ratarata masing-masing kelas. Deskripsi data mengenai keterampilan berpikir kritis siswa disajikan dalam Tabel 1. 
Tabel 1. Data Nilai Rata-rata Keterampilan Berpikir Kritis di Kelas Eksperimen dan Kontrol

\begin{tabular}{|c|c|c|c|c|c|c|}
\hline Hasil & Kelas & $\mathbf{n}$ & $\overline{\mathbf{x}}$ & $\underset{\mathbf{m i n}}{\mathbf{x}}$ & $\begin{array}{c}\mathbf{x} \\
\mathbf{m a x}\end{array}$ & $\mathbf{S}$ \\
\hline \multirow[t]{2}{*}{ Pretest } & Eksperimen & 29 & 47,52 & 22,00 & 83,00 & 16,88 \\
\hline & Kontrol & 26 & 42,15 & 22,00 & 77,00 & 12,58 \\
\hline \multirow[t]{2}{*}{ Posttest } & Eksperimen & 29 & 58,10 & 28 & 94 & 18,16 \\
\hline & Kontrol & 26 & 47,42 & 28 & 88 & 14,68 \\
\hline
\end{tabular}

Keterangan :

$\mathrm{n} \quad=$ Jumlah Siswa;

$\mathrm{x}^{-} \quad=$ Nilai rata-rata;

Xmax = Nilai maksimum;

$\mathrm{Xmin}=$ Nilai minimum;

$\mathrm{s} \quad=$ Simpangan baku

Deskripsi keterampilan berpikir kelas kontrol dapat dilihat pada tabel 2 di kritis siswa berpengetahuan awal tinggi bawah.

dan rendah pada kelas eksperimen dan dan

Tabel 2. Data Nilai Rata-rata Keterampilan berpikir kritis di Kelas Eksperimen dan Kontrol Berdasarkan Pengetahuan Awal

\begin{tabular}{|c|c|c|c|c|c|c|c|c|}
\hline No & Kelas & Hasil & $\begin{array}{l}\text { Pengetahuan } \\
\text { Awal }\end{array}$ & $\mathbf{N}$ & $\overline{\mathbf{x}}$ & $\mathbf{X}_{\min }$ & $\mathbf{X}_{\max }$ & $\mathbf{S}$ \\
\hline \multirow[t]{4}{*}{1} & \multirow{4}{*}{$\begin{array}{l}\text { Eksperi } \\
\text { men }\end{array}$} & \multirow[t]{2}{*}{ Pretest } & Rendah & 15 & 36,93 & 22,00 & 55,00 & 9.87 \\
\hline & & & Tinggi & 14 & 58,86 & 28,00 & 83,00 & 15.52 \\
\hline & & \multirow[t]{2}{*}{ Postest } & Rendah & 15 & 47,93 & 28,00 & 66,00 & 12.16 \\
\hline & & & Tinggi & 14 & 69,79 & 39,00 & 94,00 & 16.19 \\
\hline \multirow[t]{4}{*}{2} & \multirow[t]{4}{*}{ Kontrol } & \multirow[t]{2}{*}{ Pretest } & Rendah & 12 & 40,17 & 28,00 & 61,00 & 10.53 \\
\hline & & & Tinggi & 14 & 43,86 & 22,00 & 77,00 & 14.28 \\
\hline & & \multirow[t]{2}{*}{ Postest } & Rendah & 12 & 43,75 & 28,00 & 61,00 & 11.19 \\
\hline & & & Tinggi & 14 & 49,07 & 28,00 & 88,00 & 15.09 \\
\hline
\end{tabular}

Keterangan :
$\mathrm{n} \quad=$ Jumlah Siswa;
$\mathrm{x}^{-} \quad=$ Nilai rata-rata;
$\mathrm{Xmax}=$ Nilai maksimum;
Xmin $=$ Nilai minimum; 
Dari data nilai pengetahuan awal dan data nilai keterampilan Berpikir kritis baik pretest dan posttest maka dilakukanlah uji prasyarat analisis berupa uji normalitas dan uji homogenitas.

Dari uji normalitas yang dilakukan terhadap pengetahuan awal dan nilai keterampilan berpikir jritis menggunakan uji Liliefors didapatkan data tersebut terdistribusi normal dan pada penghitungan Uji Homogenitas melalui Uji $F$ terhadap data pengetahuan awal dan berpikir kritis dapat disimpulkan kedua kelas bervarians homogen.

Setelah uji prasyarat terpenuhi, maka dilakukanlah uji hipotesis :

1. Perbandingan Keterampilan Berpikir Kritis Siswa yang menggunakan Model Learning Cycle $7 E$ dengan Keterampilan Berpikir Kritis Siswa yang menggunakan Metode Eksperimen

Keterampilan berpikir kritis siswa yang menggunakan model Learning Cycle $7 E$ lebih tinggi daripada keterampilan berpikir kritis siswa yang menggunakan metode eksperimen". Berdasarkan hasil perhitungan uji Anava diperoleh hasil analisis dari kedua kelas eksperimen dan kontrol pada tabel 11 berikut

Hasil perhitungan dengan menggunakan uji ANAVA diperoleh bahwa pada tes awal (pretest) Fhitung $=1,76$ pada taraf $\alpha=0,05$ diperoleh Ftabel $=4,023$ karena Fhitung < Ftabel sehingga H0 diterima artinya tidak terdapat perbedaan yang signifikan antara kelas kontrol dengan kelas eksperimen pada rata-rata nilai tes awal keterampilan berpikir kritis yang berarti kedua kelas memiliki kemampuan awal yang sama. Kemudian pada rata-rata tes akhir (posttest) berdasarkan perhitungan anava satu arah diperoleh Fhitung = 6,21 pada taraf $\alpha=0,05$ diperoleh Ftabel $=4,023$ karena Fhitung $>$ Ftabel H0 ditolak sehingga terlihat adanya perbedaan yang signifikan antara kelas kontrol dan kelas eksperimen dimana nilai rata-rata kelas eksperimen memiliki rata-rata yang lebih tinggi dibanding kelas kontrol, artinya H0 ditolak dan $\mathrm{H} 1$ diterima yaitu Keterampilan berpikir kritis siswa yang menggunakan model Learning Cycle $7 E$ secara signifikan lebih tinggi dari pada keterampilan berpikir kritis IPA siswa yang menggunakan metode eksperimen. 
2. Keterampilan Berpikir Kritis Siswa berdasarkan Pengetahuan Awal Tinggi yang menggunakan Model Learning Cycle $7 E$ dan Metode Eksperimen

Hasil pengujian hipotesis kedua menunjukkan bahwa secara umum kelompok siswa yang mempunyai pengetahuan awal tinggi memperoleh keterampilan berpikir kritis belajar yang tinggi dengan menggunakan model Learning Cycle $7 E$ daripada menggunakan metode eksperimen $\mathrm{Hal}$ ini ditunjukkan pada pengujian hipotesis kedua Tabel 12 berikut.

Hasil perhitungan dengan menggunakan Anava Satu Arah diperoleh Fhitung $=9$, 98 pada taraf nyata $\alpha=0,05$ di peroleh Ftabel $=$ 4,23 karena Fhitung > Ftabel, H0 ditolak artinya terdapat perbedaan yang signifikan antara kelas kontrol dengan kelas eksperimen dimana nilai rata-rata kelas eksperimen memiliki rata-rata yang lebih tinggi dibanding kelas kontrol, artinya H0 ditolak dan H1 diterima yaitu keterampilan berpikir kritis siswa yang memiliki pengetahuan awal tinggi yang diajar dengan model Learning Cycle $7 E$ secara signifikan lebih tinggi dari pada keterampilan berpikir kritis siswa yang memiliki pengetahuan awal tinggi yang diajar dengan metode eksperimen.

3. Keterampilan Berpikir Kritis Siswa berdasarkan Pengetahuan Awal Rendah yang menggunakan Model Learning Cycle $7 E$ dan Metode Eksperimen

Hasil pengujian hipotesis ketiga menunjukkan bahwa secara umum kelompok siswa yang mempunyai pengetahuan awal rendah memperoleh keterampilan berpikir kritis belajar yang tidak berbeda dengan menggunakan metode eksperimen.

Hasil perhitungan dengan menggunakan Anava Satu Arah diperoleh Fhitung $=0,65$ pada taraf nyata $\alpha=0,05$ diperoleh Ftabel $=4,30$ karena Fhitung $<$ Ftabel, H0 diterima artinya tidak terdapat perbedaan yang signifikan antara keterampilan berpikir kritis siswa yang memiliki pengetahuan awal rendah yang menggunakan model learning Cycle $7 \mathrm{E}$ dan keterampilan berpikir kritis yang memiliki pengetahuan awal rendah yang menggunakan metode eksperimen. 
4. Pengaruh Interaksi Model LC7E dan Pengetahuan awal Terhadap Keterampilan berpikir kritis

Hipotesis 4 menggunakan Uji ANAVA dua arah dengan metode Unweighted mean. Hasil perhitungan hipotesis 4 bahwa nilai Fhitung = 4,098 $>$ Ftabel $=4,00$. Hal ini berarti $\mathrm{H} 0$ ditolak dan $\mathrm{H} 1$ diterima artinya efek faktor pengetahuan awal mempengaruhi model pembelajaran terhadap keterampilan berpikir kritis siswa.

\section{Pembahasan}

Penerapan model Learning Cycle $7 E$ memberi dampak positif terhadap keterampilan berpikir kritis siswa. Perpaduan antara model ini memberi dampak positif bagi guru karena membantu guru menghidupkan kembali suasana pembelajaran yang menyenangkan dan tidak membosankan. Dampak positif bagi siswa adalah membuka kembali pikiran anak untuk mampu berpikir secara mendalam.

Hasil pengujian hipotesis pertama mengungkapkan bahwa secara keseluruhan Keterampilan berpikir kritis siswa kelas eksperimen yang menerapkan model learning Cycle $7 E$ lebih tinggi secara signifikan dibandingkan dengan kelas kontrol . Ini dapat dilihat dari nilai rata- rata posttest kelas eksperimen 58,10 dan kelas kontrol berada dibawahnya yaitu 47,42. Tingginya perolehan nilai rata-rata kelas eksperimen ini dibandingkan kelas kontrol disebabkan oleh efek perlakuan yang diberikan pada kelas eksperimen yaitu model learning Cycle $7 E$. Ini didukung juga oleh hasil penelitian Ozlem Mecit (2006) yang mengungkapkan bahwa Model Learning Cycle 7E menyebabkan perbaikan lebih baik pada keterampilan berpikir kritis daripada metode konvensional".

Model learning Cycle 7E pada kelas eksperimen dapat meningkatkan cara belajar siswa menuju lebih baik dan keterampilan berpikir kritisnya meningkat lebih baik karena model ini berpusat pada siswa, membantu siswa berlajar menemukan sendiri, menggali sendiri pemikirannya, siswa bisa belajar bagaimana berpikir lebih baik, dan kritis. Ini sesuai juga dengan penelitian $\mathrm{Ni} \mathrm{Pt}$. Meldania dkk (2015:46) yang menyatakan bahwa pembelajaran yang menggunakan model Learning Cycle 7E meningkatkan aktifitas dan hasil belajar siswa karena model ini mengutamakan pengalaman siswa selain itu dapat membentuk siswa yang aktif, kritis dan kreatif.

Learning Cycle 7E yang merupakan bagian dari pembelajaran konstrustivis mengutamakan pengetahuan atau 
pemahaman awal yang nantinya akan menjadi pijakan menuju pengetahuan baru. Berdasarkan hasil di atas rata-rata keterampilan berpikir kritis siswa baik eksperimen maupun kontrol terlihat masih rendah meskipun ada beberapa indicator yang sudah bisa dipenuhi oleh siswa. Dibutuhkan kemampuan guru dan pendidik untuk banyak melakukan upayaupaya dalam mengembangkan kemampuan berpikir kritis mereka melalui variasi metode pembelajaran, percobaan, saling berdiskusi dan lain-lain. Sesuai dengan pendapat Bloom (Dalam Iskandar, 2009:32) bahwa pemikiran kritis dapat diperbaiki melalui latihan berpikir tingkat tinggi yaitu dari tingkat aplikasi sampai pada tingkat evaluasi. Latihan berpikir tingkat tinggi ini perlu dirancang oleh guru sebagai pengalaman belajar siswa. Selain itu, menurut Sagala (Iskandar, 2009:110). Senada disampaikan oleh Lawson (Dalam Mecit, 2006:15) bahwa "aspek kunci dari belajar pelajaran siklus adalah bahwa mereka berusaha untuk melibatkan para siswa dalam pertanyaan bermakna dengan tujuan meningkatkan kemampuan berpikir mereka dan dengan tujuan membantu siswa mengkonstruksi konsep-konsep yang bermakna".

Pengujian hipotesis yang kedua telah membuktikan bahwa model Learning Cycle 7E memberi dampak kepada
Keterampilan Berpikir siswa. Dalam menemukan konsep/prinsip siswa yang memiliki pengetahuan awal tinggi kurang membutuhkan bantuan dan bimbingan dari teman. Siswa yang tinggi pengetahuan awalnya proses pembelajarannya lebih aktif karena mampu menghubungkan dengan pembelajran lama. Mereka cepat menemukan konsep pembelajran. Hal ini karena ketika tahapan elicit dan engangement memberi informasi baru dan tambahan yang dapat menstimulus otak untuk lebih cepat memahami dan menemukan sendiri konsep/prinsip pembelajaran.

Pada saat pengetahuan baru masuk dengan sadar, otak menciptakan berkasberkas baru (skema baru) atau menambahkan informasi tersebut ke berkas yang telah ada. Selama suatu priode, seluruh system pemberkasan tersebut mengembang dan meluas (Anderson dan person dalam Eka, 2016:97). Sebagai contoh ketika anak ditanya tentang es krim, pertanyaan ini menstimulus siswa untuk memanggil informasi yang tersimpan dalam memori jangka panjang (recognizion), sehingga siswa dapat mengaitkan dengan pengalaman belajar yang mereka miliki dengan informasi baru yang mereka terima, hal inilah yang membuat mereka lebih cepat menemukan konsep baru. 
Hasil pengujian hipotesis ketiga menunjukkan bahwa secara umum kelompok siswa yang mempunyai pengetahuan awal rendah memperoleh keterampilan berpikir kritis belajar yang tidak berbeda dengan menggunakan metode eksperimen. Hal diatas terjadi karena pembelajaran dengan model learning Cycle $7 E$ belum mampu menstimulus kognitif siswa yang mempunyai pengetahuan awal rendah. Keterampilan berpikir kritis yang mengedepankan bagaimana seseorang mampu mengkonstruksi pengetahuannya dimulai dari bagaimana ia mengaitkan pengetahuan awalnya dengan informasi baru karena ini merupakan bagian awal dari tahap Learning Cycle $7 E$ yaitu fase elicit.

Selain itu perkembangan anak yang belum mampu berinteraksi dan bekerjasama secara aktif dengan temannya dalam kelompok pada saat berdiskusi bisa juga menjadi penyebab kurang bermaknanya sebuah pembelajaran. Hal ini bisa saja terjadi karena kurangnya minat siswa yang mempunyai pengetahuan rendah belajar mandiri, masih belum berani bertanya dan berdiskusi. Mereka belum ikut aktif dalam kelompok dan ketika tahapan awal pembangkitan minat dan pemunculan pegetahuan awal mereka belum nyambung dengan materi yang akan diajarkan . Selain itu, ketika melaksanakan tahap eksplorasi dan elaborasi, siswa yang mempunyai pengetahuan rendah belum mampu mengeksplorasikan dan menerapkan konsep baru secara tepat pada kehidupan sehingga keterampilan berpikir kritis mereka tidak terasah. Berbeda dengan siswa yang berpengetahuan awal tinggi, mereka langsung berinteraksi dengan pengetahuan baru mereka sehingga siswa yng rendah menjadi tertinggal. Disini dibutuhkan perhatian yang besar bagi guru untuk betul-betul mengetahui sejauh mana pengetahuan awal siswa terghadap materi yang akan diajarkan.

Hasil perhitungan ANAVA dua arah untuk pengujian hipotesis keempat menyimpulkan terdapat interaksi antara model pembelajaran dan pengetahuan awal siswa dalam mempengaruhi keterampilan berpikir kritis belajar IPA siswa. Berarti efek faktor model pembelajaran masingmasing berjalan dan mempengaruhi keterampilan berpikir kritis atau terdapat interaksi antara metode pembelajaran dan kategori pengetahuan awal belajar terhadap keterampilan berpikir kritis siswa. 
SIMPULAN

Berdasarkan pengujian dan pembahasan hipotesis yang sudah dilakukan, maka diperoleh kesimpulan berikut ini

1. Keterampilan berpikir kritis siswa yang menggunakan model Learning Cycle $7 E$ lebih tinggi daripada keterampilan berpikir kritis siswa yang menggunakan metode eksperimen, Sehingga model Learning Cycle $7 E$ dapat meningkatkan keterampilan berpikir kritis siswa SD.

2. Keterampilan berpikir kritis siswa dengan pengetahuan awal tinggi yang menggunakan model Learning Cycle $7 E$ lebih tinggi daripada keterampilan berpikir kritis siswa yang menggunakan metode eksperimen. Hal ini karena adanya efek pengetahuan awal berpengaruh besar dalam membangun pengetahuan baru dengan bantuan pengalaman sebelumnya.

3. Keterampilan berpikir kritis siswa dengan pengetahuan awal rendah yang menggunakan model Learning Cycle $7 E$ tidak jauh berbeda dari pada keterampilan berpikir kritis siswa menggunakan metode Eksperimen. Hal ini karena siswa yang memiliki pengetahuan awal rendah belum mampu menghubungkan tahap-tahap pada model karena pada tahap awal (elicit) kelompok ini tidak bisa mengaitkan keterampilan berpikir mereka dengan konsep baru yang dipelajari.

4. Terdapat interaksi antara penggunaan model Leraning Cycle $7 E$ dan pengetahuan awal siswa terhadap keterampilan berpikir kritis siswa. Hal ini berarti, masing-masing faktor (model pembelajaran dan pengetahuan awal saling ketergantungan dan mempengaruhi ). Hal ini dilihat dari siswa yang ber pengetahuan awal tinggi yang diajarkan dengan menggunakan model learning Cycle $7 E$ keterampilan berpikir kritisnya meningkat, namun siswa dengan pengetahuan awal rendah yang diajarkan dengan menggunakan pembelajaran model learning Cycle $7 E$ menunjukkan hasil yang tidak berbeda dengan siswa yang diajar tidak model lain.

\section{DAFTAR PUSTAKA}

Anderson, L. W., dkk. 2010. Kerangka Landasan untuk Pembelajaran, Pengajaran dan Assesmen: Revisi Taksonomi Pendidikan Bloom. Terjemahan oleh Agung Prihantoro.Yogyakarta: Pustaka Pelajar

Bailin, S. 2002. Critical Thinking and Science Education. Science and 
Education Netherland. 2002 (11) : 361-375

Balta, Nuri \& Sarac, H. (2016). The Effect of $7 E$ Learning Cycle on Learning in Science Teaching : A Meta-Analysis Study. European Journal of Educational Research, 5(2), 6172.

Eisenkraft, A. 2003. Expanding the $5 E$ Model :A Proposed 7E Model emphasize "transfer of learning" and the Importance of eliciting prior Understanding. National Science Teacher Association (NSTA). The Science Teacher, Vol.70, No.6 p.56.

Ennis, R.H. 2011. The Nature of Critical Thinking : An Outline of Critical Thinking Dispositions and Abilities. Disampaikan pada Sixth International Conference on Thinking at MIT, Cambridge, May Juli 1994 (last Revised May 2011). Diakses dari situs http: // faculty. Education.illinios.edu/rhennis/d ocuments/thenatureofCriticalThi nking_51711_000.pdf, pada tanggal 20 April 2016.

Fembriani, Khumedi, Catharina, T.A. 2015. Pengembangan Perangkat Pembelajaran IPA Model Learning Cycle 7e Untuk Meningkatkan Kemampuan Berpikir Kritis. Journal of Primary Education.4 (1).

Fisher, A. 2009. Berfikir Kritis sebuah pengantar . Terjemahan Benyamin Hadinata. Jakarta: Erlangga
Hapsari, Iriani, I. 2016. Psikologi Perkembangan Anak. Jakarta: Penerbit Indeks

Marzano, Robert, J \& Heflebower, T. 2012. Teaching and Assessing $21^{\text {st }}$ Century Skills. USA : Marzano Research Laboratory.

Mecit, O. 2006. The Effect of 7E Learning Cycle Model on The Improvement of Fifth Grade Students Critical Thinking Skills.Tesis.

Meldania, Ni.Pt, dkk. 2015. Pengaruh Model Pembelajaran Learning Cycle 7E Bermuatan Tri HIta Karana terhadap Hasil Belajar IPA Siswa kelas V. Journal of Primary Education.4 (1).

Novarisa, E. 2016. Pengaruh LKS dan Kemampuan Awal terhadap Kompetensi IPA siswa kelas VII pada Pembelajaran dengan Model Guided Discovery di SMPIT Al Ihsan Boarding School Riau. Tesis. Universitas Negeri Padang : Padang

Susanto, A. 2013. Teori Belajar dan Pembelajaran di Sekolah Dasar. Jakarta: Kencana Prenada Media Group.

Wijayanti, D.A., dkk. 2015. Analisis Kemampuan Berpikir Kritis Siswa kelas $V$ pada Pembelajaran IPA di 3 SD Gugus X Kecamatan Buleleng. e-Journal PGSD Universitas Pendidikan Ganesha Jurusan PGSD Volume: 3 No: 1 Tahun 20. 